\title{
RANCANG BANGUN DAN ANALISIS QoS (QUALITY OF SERVICE) MENGGUNAKAN METODE HTB (HIERARCHICAL TOKEN BUCKET) PADA RT/RW NET PERUMAHAN PRASANTI 2
}

\author{
Syaiful Ahdan ${ }^{1)}$, Okta Firmanto ${ }^{2)}$, Suci Ramadona ${ }^{3)}$ \\ ${ }^{1)}$ Teknologi Informasi, Fakultas Teknik \& Ilmu Komputer, Universitas Teknokrat Indonesia \\ ${ }^{2)}$ Informatika, Fakultas Teknik \& Ilmu Komputer, Universitas Teknokrat Indonesia \\ ${ }^{1,2)}$ Jl. H.ZA Pagaralam, No 9-11, Labuhanratu,Bandarlampung \\ ${ }^{3)}$ Teknik Elektro,Politeknik Caltex Riau \\ ${ }^{3)}$ Jl. Umban Sari, No.1, Rumbai Pekanbaru, Riau \\ Email : syaifulahdan@teknokrat.ac.id ${ }^{1)}$, oktafirmantol@gmail.com ${ }^{2),}$,suci.ramadona@pcr.ac.id ${ }^{3)}$
}

\begin{abstract}
Abstrak - Permasalahan tentang kontinuitas bandwidth pada sebuah jaringan sering kali terjadi, hal tersebut dikarenakan belum memanfaatkan Quality of Service secara optimal. Tanpa adanya manajemen bandwidth maka akan mengakibatkan terjadinya masalah pada bandwidth yang diterima oleh node pada suatu jaringan. Untuk meminimalkan masalah kontinuitas pada bandwidth maka perlu diterapkan metode HTB Hierarchical Token Bucket pada manajemen bandwidth dengan menggunakan router, agar dapat mendapatkan hasil QoS yang baik maka perlunya melakukan pengujian terdahap bandwidth yang digunakan dengan menggunakan beberapa parameter pengujian yaitu: Delay, Throughput, Packetloss dan Jitter. Hasil dari perhitungan dan analisis QoS yang didapatkan setelah penerapan metode HTB yaitu: pada paket berukuran 43,01MB delay yang didapatkan sebesar 2,9 ms dan hasil sebelum penerapan HTB adalah 5,1 ms, dengan menggunakan HTB delay mengalami optimasi sebesar $\mathbf{7 2 , 9 \%}$ dari delay sebelumnya. Untuk hasil throughput nilai yang didapatkan sebesar 2535 Kbps dan hasil sebelum penerapan HTB sebesar 1657 kbps, dengan menggunakan HTB Troughput mengalami optimasi sebesar $34,6 \%$ dari nilai troughput sebelumnya. untuk nilai packetloss sama-sama tidak mengalami kehilangan packet yaitu dengan hasil 0\%, untuk hasil jitter nilai yang didapatkan sebesar $2,95 \mathrm{~ms}$ dan hasil sebelum penerapan metode HTB sebesar 5,06 ms dengan menggunakan HTB Jitter mengalami optimasi sebesar $71.5 \%$.
\end{abstract}

Kata kunci: Quality of Service, HTB, Management Bandwidth.

\section{PENDAHULUAN}

\section{A. Latar Belakang}

Tingkat pertumbuhan trafic internet saat ini terus meningkat berdasarkan semakin banyaknya pengguna. Salah satu sumber terkemuka yang memantau tingkat lalu lintas internet menunjukan bahwa tingkat pertumbuhan saat ini adalah 40 hingga 50\%, oleh karena itu kemampuan jaringan, khususnya kemampuan transmisi, routing dan switching perlu menyesuaikan arus lalu lintas agar pertumbuhan internet yang stabil dapat dipertahankan [1]. QoS (Quality of Service) adalah metode pengukuran tentang seberapa baik jaringan dan merupakan usaha untuk mendefinisikan karateristik dan sifat suatu layanan. QoS digunakan untuk mengukur sekumpulan attribut kinerja yang telah di spesifikasikan dan biasanya diasosiasikan dengan suatu layanan [2]. QoS dalam suatu jaringan adalah suatu permintaan untuk melakukan suatu kinerja yang diperlukan untuk mentransfer paket-paket IP dalam suatu jaringan [3]. Dalam dekade terakhir, parameter QoS telah menimbulkan tantangan besar bagi operator jaringan, sebagian dikarenakan jumlah permintaan lalu lintas yang meningkat secara bervariasi, internet adalah teknologi best-effort, oleh karena itu sangat tidak optimal untuk layanan transportasi yang sensitif terhadap delay. Seiring dengan tuntutan yang meningkat pada kebutuhan layanan jaringan maka diperlukan usaha keras untuk memberikan layanan yang berkualitas baik kepada pelanggan [4]. Masalah penyediaan QoS internet telah menjadi bidang penelitian yang sangat aktif selama bertahun tahun. Dari arsitektur layanan terpadu sebelumnya (IntServ) hingga arsitektur Differentiated Services (Diffserv), banyaknya mekanisme kontrol QoS terutama di area penjadwalan paket dan algoritma manajemen antrian telah banyak diusulkan [5]. QoS adalah mekanisme pengukuran untuk mengetahui seberapa baik aplikasi dan layanan yang berjalan di jaringan. QoS bertujuan untuk memberikan kualitas layanan yang lebih baik dan layanan yang berbeda beda dengan infrastruktur jaringan yang sama [6]. Tujuan dari pengendalian lalu lintas adalah untuk memberikan jaminan yang berkaitan dengan kinerja jaringan, QoS jaringan dan pengguna. Salah satu teknik yang dapat mengimplementasikan alokasi sumber daya yang efisien adalah dengan menggunakan HTB. Kontrol HTB menggunakan penggunaan bandwidth keluar (egress bandwidth) pada tautan yang diberikan. Selain itu, HTB memungkinkan berbagi satu tautan fisik ke beberapa tautan yang disimulasikan lebih lambat [7]. Beberapa masalah yang dihadapi warga perumahan prasanti 2 dalam membangun jaringan internet adalah mahalnya biaya instalasi jaringan dan biaya internet. Oleh karna itu perlu adanya pembangun jaringan internet yang dapat terjangkau oleh warga perumahan prasanti 2 sukarame. 
Dalam hal pembangunan jaringan ini perlu juga diperhatikan bagaimana jaringan tersebut dapat berjalan dengan baik dengan mementingkan QoS.

Berdasarkan hal tersebut maka fokus pada penelitian ini terletak pada bagaimana membangun jaringan pada perumahan prasanti 2 dan menganalisis QoS dengan cara mengimplementasikan metode HTB.

\section{B. Landasan Teori}

\section{Manajemen Bandwidth}

Manajemen bandwidth yang berfokus pada kinerja jaringan adalah salah satu masalah yang penting pada saat ini dalam aplikasi dan sistem teknik komputer terutama dalam manajemen jaringan [8]. Bandwidth mengacu pada jumlah informasi yang dapat dikirimkan pada suatu waktu tertentu melalui media transmisi, secara umum bandwidth jaringan adalah ukuran bit rate dari sumber daya komunikasi data yang tersedia yang dapat dinyatakan dalam bit/ detik atau kelipatan (kilobit /s, megabits /s dll) [9]. Bandwidth Management adalah suatu cara yang dapat digunakan untuk memenuhi kebutuhan layanan jaringan [10].

\section{Metode HTB (Hierarchical Token Bucket)}

HTB adalah metode antrian classfull yang berguna untuk menangani berbagai jenis trafik, HTB memungkinkan untuk membuat struktur antrian secara hirarkis dan menentukan hubungan antrian seperti (parent-child) atau (child-child). Tiga langkah dasar untuk membuat HTB adalah : (

1. Match and mark Traffic yaitu : membuat klasifikasi lalu lintas untuk digunakan lebih lanjut yang terdiri dari satu atau lebih parameter yang cocok untuk memilih paket untuk kelas tertentu.

2. Create rules (Policy) to mark Traffic yaitu : membuat klasifikasi lalu lintas untuk digunakan lebih lanjut yang terdiri dari satu atau lebih parameter yang cocok untuk memilih paket untuk kelas tertentu.

3. Attach policy for specific interface(-s) yaitu : Menambahkan suatu kebijakan (policy) untuk semua antarmuka (Global-in, global-out atau global-total), untuk antar muka tertentu atau untuk parent-quеме tertentu.

HTB juga memiliki kategori limitasi diantaranya adalah :

1. CIR (Committed Information Rate) adalah proses menentukan batas bawah atau minimal trafik (limit-at) yang dapat diperoleh antrian. Limit-at membatasi minimal trafik dari suatu antrian, tidak peduli dalam kondisi apapun antrian tidak akan mendapati traffic di bawah batas ini.

2. MIR (Maximal Information Rate) adalah skenario terbaik, yaitu dengan cara menentukan batas atas atau menggunakan maksimal trafik (max-limit) yang bisa diperoleh antrian. max-limit akan membatasi trafik suatu antrian secara maksimal dan setiap antrian akan mencapai batas ini jika parent masih memiliki cadangan bandwidth [11].

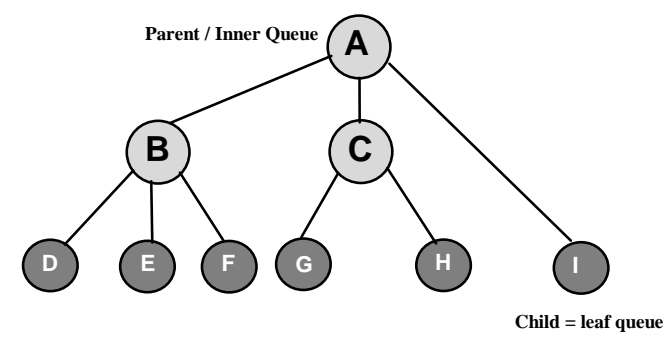

Gambar 1. Struktur Hirarki HTB

\section{Failover}

Failover adalah mode yang secara otomatis dapat mengarahkan lalu lintas ke gateway alternatif yang masih ada jika salah satu gateway gagal [12], failover dapat memulihkan konektifitas dengan melakukan koneksi kembali dengan gateway/controllers yang ada [13]. Failover dalam jaringan komunikasi adalah proses memindahkan tugas secara instan dari komponen yang gagal ke komponen redundan yang sama untuk menghindari gangguan dan mempertahankan operasi, automated failover adalah kemampuan untuk secara cepat mengubah rute data secara otomatis dari komponen yang gagal seperti server atau koneksi jaringan, menjadi komponen yang berfungsi [14].

\section{Quality of Service (QoS)}

Masalah-masalah penting dalam jaringan internet adalah ketersediaan bandwidth, packet loss, delay dan jitter atau delay variance. Teknologi QoS dapat diaktifkan di perangkat jaringan layer 2 dan layer 3 . untuk menjamin kualitas komunikasi end-to-end, dan diperlukan proses pemetaan dari lapisan 2 ke lapisan 3 [15].

QoS mengacu pada kemampuan jaringan untuk menyediakan layanan yang lebih baik pada trafik jaringan tertentu melalui teknologi yang berbeda-beda. QoS menawarkan kemampuan untuk mendefinisikan atribut-atribut layanan jaringan yang disediakan, baik secara kualitatif maupun kuantitatif. Pada Tabel I diperlihatkan nilai presentase dari QoS $[2,6,15]$.

Tabel 1. Indeks Parameter QoS

\begin{tabular}{|c|c|c|}
\hline Nilai & Persantase (\%) & Indeks \\
\hline $3,8-4$ & $95-100$ & Sangat Memuaskan \\
\hline $3-3,79$ & $75-94,75$ & Memuaskan \\
\hline $2-2,99$ & $50-74,75$ & Kurang Memuaskan \\
\hline $1-1,99$ & $25-49,75$ & Jelek \\
\hline
\end{tabular}

Parameter Quality of Service terdiri dari :

\section{Throughput}

Throughput merupakan kecepatan (rate) transfer data efektif, yaitu diukur dalam bps. Throughput merupakan jumlah total kedatangan paket yang sukses yang diamati pada tujuan selama interval waktu tertentu dibagi oleh durasi interval waktu tersebut [2]. Throughput dapat dihitung dalam persamaan berikut : 
Throughput Error! Reference source not found.

$=\frac{\text { Paket data diterima }}{\text { Total waktu pengiriman data }}$

Tabel 2. Kategori Throughput

\begin{tabular}{|l|c|c|}
\hline \multicolumn{1}{|c|}{ Kategori Throughput } & Throughput & Indeks \\
\hline Sangat Bagus & $100 \%$ & 4 \\
\hline Bagus & $75 \%$ & 3 \\
\hline Sedang & $50 \%$ & 2 \\
\hline Jelek & $<25 \%$ & 1 \\
\hline
\end{tabular}

\section{Delay (Latency)}

Adalah waktu yang dibutuhkan data untuk menempuh jarak dari asal ketujuan. Delay dapat dipengaruhi oleh jarak, media fisik, kongesti atau juga waktu proses yang lama [2]. Menurut versi TIPHON, besarnya delay dapat dihitung dengan persamaan berikut:

$$
\text { Delay }=\quad \frac{\text { Total delay }}{\text { Total packet yang diterima }}
$$

Tabel 3. Kategori Delay

\begin{tabular}{|l|c|c|}
\hline \multicolumn{1}{|c|}{ Kategori Latensi } & Besar delay & Indeks \\
\hline Sangat Bagus & $<150 \mathrm{~ms}$ & 4 \\
\hline Bagus & $150 \mathrm{~s} / \mathrm{d} 300 \mathrm{~ms}$ & 3 \\
\hline Sedang & $300 \mathrm{~s} / \mathrm{d} 450 \mathrm{~ms}$ & 2 \\
\hline Jelek & $>450 \mathrm{~ms}$ & 1 \\
\hline
\end{tabular}

\section{Jitter (Variasi kedatangan paket)}

Jitter disebut juga variasi delay. Jitter disebabkan karena variasi-variasi dalam panjang antrian, dalam waktu pengelolaan data, dan juga dalam waktu penghimpuanan ulang paket-paket diakhiri perjalanan jitter, jitter berhubungan dengan latency [2]. Jitter dapat dihitung dengan persamaan berikut :

$$
\text { Jitter }=\quad \frac{\text { Total variasi delay }}{\text { total paket yang diterima }}
$$

Untuk mencari total variasi delay diperoleh dari penjumlahan sebagai berikut :

(delay2-delay1)+(delay3-delay2)+........(delay n- delay $(\mathrm{n}-1))$

Tabel 4. Kategori Jitter

\begin{tabular}{|l|c|c|}
\hline \multicolumn{1}{|c|}{ Kategori Degradasi } & Jitter & Indeks \\
\hline Sangat Bagus & $0 \mathrm{~ms}$ & 4 \\
\hline Bagus & $0 \mathrm{~s} / \mathrm{d} 75 \mathrm{~ms}$ & 3 \\
\hline Sedang & $75 \mathrm{~s} / \mathrm{d} 125 \mathrm{~ms}$ & 2 \\
\hline Jelek & $125 \mathrm{~s} / \mathrm{d} 225 \mathrm{~ms}$ & 1 \\
\hline
\end{tabular}

\section{Packet Loss}

Merupakan suatu parameter yang menggambarkan suatu kondisi yang menunjukkan jumlah total paket yang hilang, dapat terjadi karena collision dan congestion pada jaringan [2]. Packet Loss dapat dihitung dengan persamaan berikut:

\section{Packetloss $=$ $\frac{\text { Packet data dikirim-Packet data diterima }}{\text { Packet data dikirim }} \times 100$}

Tabel 5. Kategori Packetloss

\begin{tabular}{|l|c|c|}
\hline \multicolumn{1}{|c|}{ Kategori Degredasi } & Packet Loss & Indeks \\
\hline Sangat Bagus & $0 \%$ & 4 \\
\hline Bagus & $3 \%$ & 3 \\
\hline Sedang & $15 \%$ & 2 \\
\hline Jelek & $25 \%$ & 1 \\
\hline
\end{tabular}

\section{ANALISIS DAN PERANCANGAN}

\section{A. Kerangka Penelitian}

Penelitian ini menggunakan kerangka penelitian yang terdiri dari beberapa tahapan antara lain : (1) Analisis, (2) Desain, (3) Simulasi, (4) Implementasi, (5) Monitoring, Manajemen, (Kesimpulan).

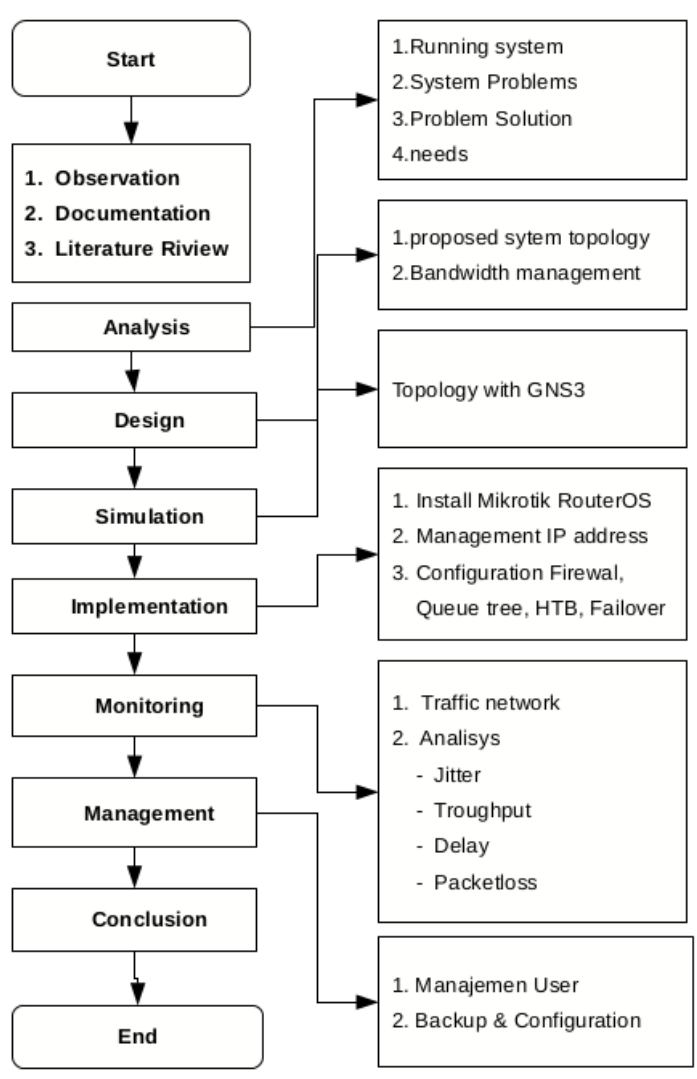

Gambar 2. Kerangka Penelitian

\section{B. ANALISIS SISTEM}

\section{Sistem Berjalan}

Berdasarkan analisis sistem yang berjalan diketahui bahwa kecepatan transfer data pada setiap komputer client yang terhubung ke jaringan memiliki kecepatan yang berbeda-beda, hal ini mengakibatkan bandwidth client tidak terbagi secara merata. Permasalahan ini terjadi karena pada jaringan yang saat ini berjalan belum menggunakan RouterBoard Mikrotik dan belum menambahkan manajemen bandwidth . 


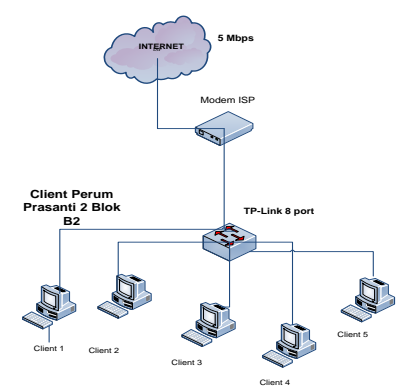

Gambar 3. Topologi Sistem Berjalan

Pembagian bandwidth yang tidak merata dapat diatasi dengan cara manajemen penggunaan bandwidth. Manajemen bandwidth dapat menggunakan RouterBoard Mikrotik. Untuk menerapkan manajemen bandwidth maka diperlukan desain topologi dengan menambahkan RouterBoard Mikrotik dan menerapkan manajemen bandwidth dengan metode HTB .

\section{Skema Jaringan yang diusulkan}

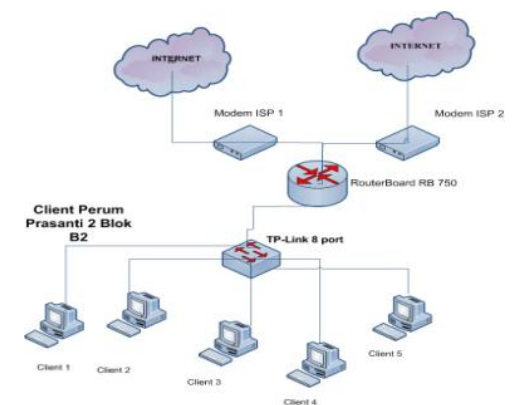

Gambar 4. Skema Jaringan yang diusulkan

\section{Skenario Pengujian}

Pada penelitian ini skenario yang akan dilakukan yaitu melakukan uji coba jaringan dengan melakukan Remote pada jaringan asli di perumahan prasanti 2 dengan menggunakan aplikasi teamviewer .

1. Pengujian Koneksi Internet

2. Pengujian Bandwidth dalam keadaan padat pengguna dan dalam keadaan sepi pengguna

3. pengujian failover yaitu backup jalur koneksi internet.

4. Analisis QoS dengan packet data $18,90 \mathrm{Mb}, 32,76$ $\mathrm{Mb}, 43,01 \mathrm{Mb}$.

\section{HASIL DAN PEMBAHASAN}

\section{A. Pengujian Manajemen Bandwidth dengan HTB}

\section{Pengujian dalam kondisi sepi pengguna}

Pengujian dilakukan pada saat kondisi jaringan tidak terdapat banyak user yang sedang online yaitu client.1, pada pengujian tahap ini hanya menggunakan 1 user, ketika kondisi sepi pengguna user yang online akan mendapatkan maksimal bandwidth yang telah disediakan, hasilnya bandwidth yang didapatkan yaitu sebesar 4.0 Mbps sesuai dengan maksimal parent yang telah dikonfigurasi user bahwa yang mendapatkan maksimal bandwidth akan ditandai pada queue tree list berwarna merah. Bandwidth maksimal yang didapat diperoleh dari konfigurasi max-limit pada queue tree child.

\section{Pengujian dalam kondisi padat pengguna}

Pengujian dilakukan pada saat kondisi jaringan terdapat banyak user yang sedang online, pada pengujian tahap ini terdapat 3 user yang sedang online diantaranya client.1, client. 2 dan client.3. Pada tahap pengujian dengan menggunakan 3 user dengan menerapkan manajemen bandwidth HTB bahwa semakin banyak user maka akan membagi bandwidth secara merata yaitu dibuktikan bahwa client.1 mendapatkan bandwidth sebesar 1724 kbps , lalu client.2 mendapatkan 1648 kbps dan client. 3 mendapatkan bandwidth sebesar $1664 \mathrm{kbps}$. pada parent TotalDownload terlihat berwarna merah karna dari jumlah bandwidth yang digunakan dari 3 user yang aktif mencapai maksimal limit pada parent Total download. Pada pengujian menggunakan 5 user yang sedang aktif. Bahwa ketika seluruh user online dan melakukan aktifitas internet maka manajemen bandwidth HTB akan membagi secara merata sehingga . QoS pada manajemen bandwidth yang menerapkan HTB bukan membatasi bandwidth tetapi lebih kepada menjaga kualitas bandwidth, tanpa adanya QoS dalam sebuah jaringan maka akan mengakibatkan permasalahan pada kontinuitas bandwidth yang diterima oleh user. Hierarchical Token Bucket (HTB) merupakan teknik QoS yang mampu memaksimalkan bandwidth yang tidak terpakai, sehingga kualitas pelayanan menjadi lebih meningkat.

\section{B. Pengujian Failover}

Metode failover bertujuan apabila salah satu link ISP bermasalah/down maka pemakaian koneksi internet dapat di-backup dengan link ISP lainnya. Kondisi yang dibahas pertama ketika link ISP 1 dengan link ISP 2 berada dalam kondisi hidup. User mencoba melakukan ping pada dns google yaitu 8.8.8.8 maka terlihat user terhubung ke internet dengan link ISP1 dan ISP2 berada dalam keadaan aktif secara bersamaan.

Kondisi selanjutnya akan dilakukan percobaan saat salah satu link ISP bermasalah / down maka pemakaian koneksi internet dapat di-backup dengan link ISP lainnya.

\section{Hasil Analisis Quality of Service}

\section{Parameter Throughput}

Pengujian dilakukan berdasarkan besaran jumlah paket yang berbeda beda di setiap skenario pengujian diantaranya 18,90 $\mathrm{Mb}, 32,76 \mathrm{Mb}$ dan 43,01 $\mathrm{Mb}$. Pengujian dilakukan antara sebelum penerapan HTB dan setelah penerapan HTB, pada setiap besaran paket pengujian dilakukan sebanyak $10 \mathrm{kali}$, dapat dilihat pada gambar 5. Hasil pengujian perbandingan dapat dilihat berdasarkan tabel 6 dan grafik troughput pada gambar 6 . 


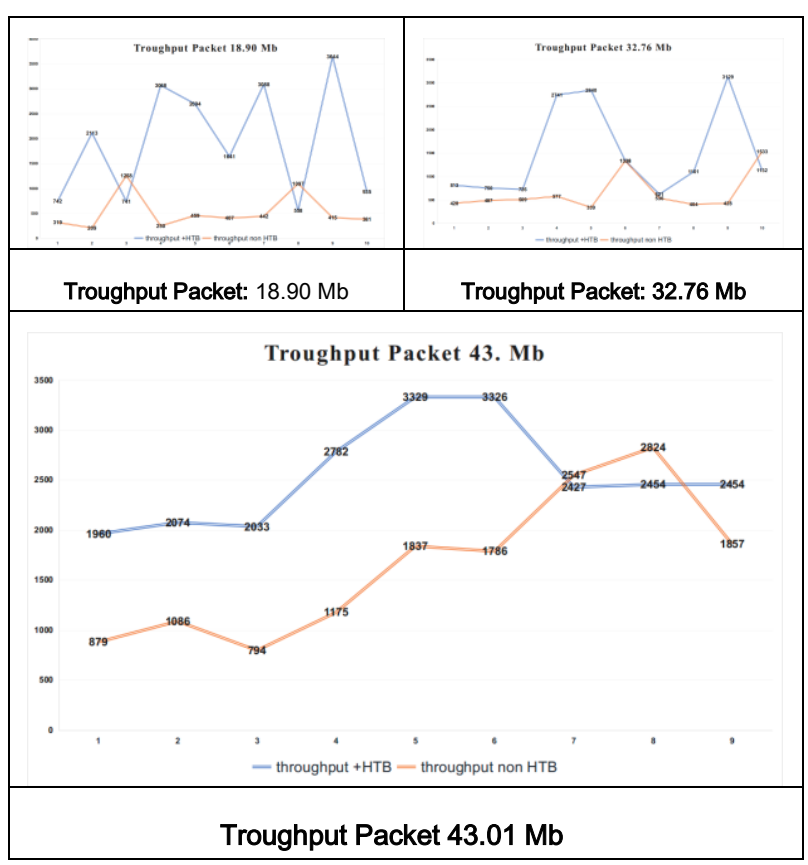

Gambar 5. Troughput berdasarkan besaran Paket

Tabel 6. Optimasi Troughput Setelah Penerapan HTB

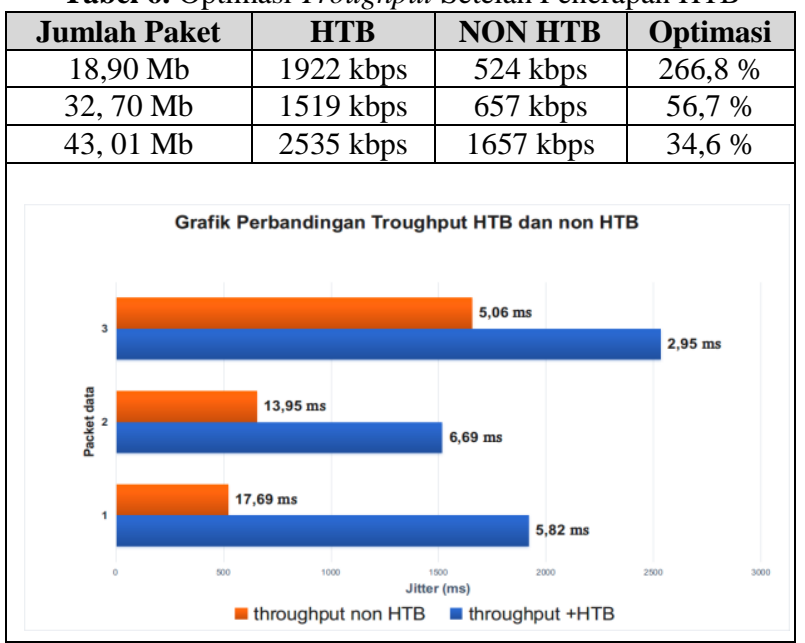

Gambar 6.Perbandingan Troughput HTB dan non HTB

\section{Parameter Delay}

Pengujian dengan menggunakan parameter delay dilakukan berdasarkan besaran jumlah paket yang berbeda beda di setiap skenario pengujian diantaranya: paket $18,90 \mathrm{Mb}$, paket $32,76 \mathrm{Mb}$ dan paket 43,01 $\mathrm{Mb}$. Pengujian dilakukan dengan cara mendownload paket sebelum penerapan HTB dan mendownload paket setelah penerapan HTB, pada setiap besaran paket pengujian dilakukan sebanyak 10 kali (dengan penerapan HTB) dan 10 Kali (tanpa menggunakan HTB), delay yang dihasilkan dari setiap pengujian dapat dilihat pada gambar 7. Perbandingan delay dapat dilihat berdasarkan tabel 7 dan grafik troughput pada gambar 8 .

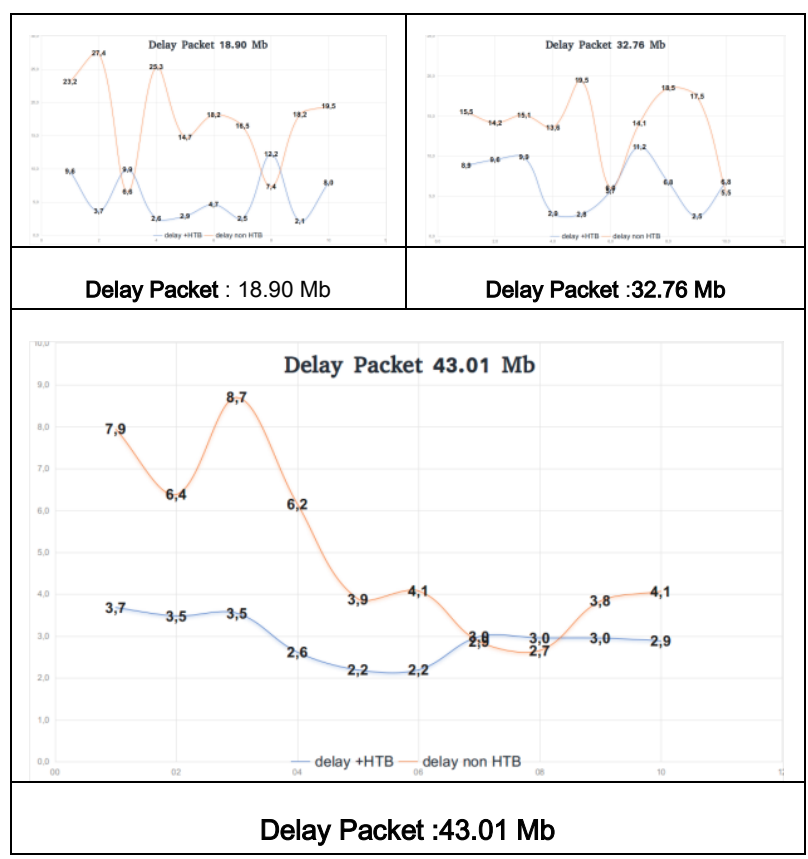

Gambar 7. Delay berdasarkan besaran Paket

Tabel 7. Optimasi delay Setelah Penerapan HTB

\begin{tabular}{|c|c|c|c|}
\hline Jumlah Paket & HTB & NON HTB & Optimasi \\
\hline $18,90 \mathrm{Mb}$ & $5,8 \mathrm{~ms}$ & $17,7 \mathrm{~ms}$ & $205,2 \%$ \\
\hline $32,70 \mathrm{Mb}$ & $6,7 \mathrm{~ms}$ & $13,9 \mathrm{~ms}$ & $107,5 \%$ \\
\hline $43,01 \mathrm{Mb}$ & $2,9 \mathrm{~ms}$ & $5,1 \mathrm{~ms}$ & $72,9 \%$ \\
\hline
\end{tabular}

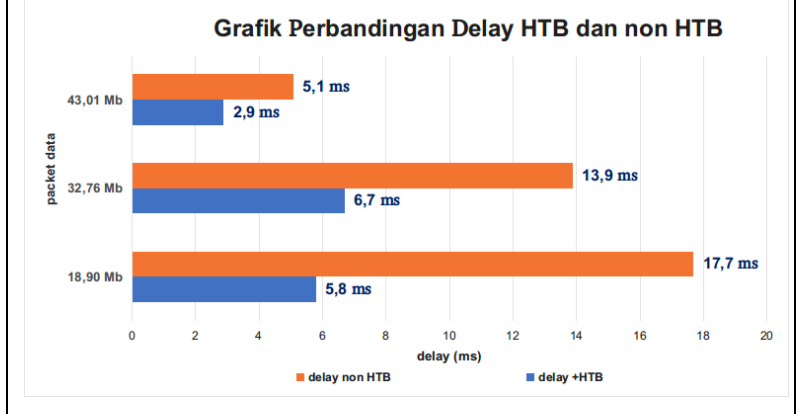

Gambar 8.Perbandingan Delay HTB dan non HTB

\section{Parameter Packet Loss}

Pengujian dengan menggunakan parameter packet loss dilakukan berdasarkan besaran jumlah paket yang berbeda beda di setiap skenario pengujian diantaranya paket $18,90 \mathrm{Mb}$, paket $32,76 \mathrm{Mb}$ dan paket $43,01 \mathrm{Mb}$. Pengujian dilakukan dengan cara mendownload paket sebelum penerapan HTB dan mendownload pakat setelah penerapan HTB, pada setiap besaran paket pengujian dilakuan sebanyak $10 \mathrm{kali}$ (dengan penerapan HTB) dan 10 kali (non HTB), packet loss yang dihasilkan dari setiap pengujian dapat dilihat pada tabel 8. Hasilnya tidak terdapat packet loss dari setiap pengujian HTB dan Non HTB nilai packet loss yaitu $0 \%$. 
Tabel 8. Optimasi Packet Loss Setelah Penerapan HTB

\begin{tabular}{|c|c|c|c|}
\hline Jumlah Paket & HTB & NON HTB & Optimasi \\
\hline $18,90 \mathrm{Mb}$ & $0 \%$ & $0 \%$ & $0 \%$ \\
\hline $32,70 \mathrm{Mb}$ & $0 \%$ & $0 \%$ & $0 \%$ \\
\hline $43,01 \mathrm{Mb}$ & $0 \%$ & $0 \%$ & $0 \%$ \\
\hline
\end{tabular}

\section{Parameter Jitter}

Pengujian dengan menggunakan parameter jitter dilakukan berdasarkan pengujian yang sama dengan pengujian delay, troughput dan packet loss, dengan besaran jumlah paket yang berbeda beda di setiap skenario pengujian diantaranya $18,90 \mathrm{Mb}, 32,76 \mathrm{Mb}$ dan 43,01 Mb. Hasil pengujian dapat dilihat berdasarkan tabel 9 dan grafik jitter pada gambar 10 .

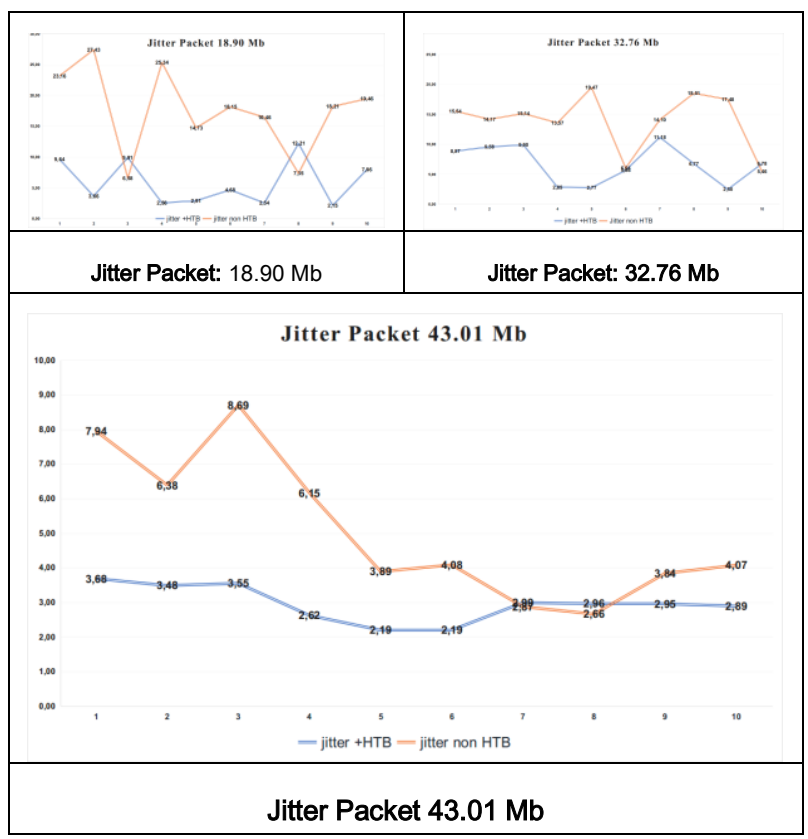

Gambar 9. Jitter berdasarkan besaran Paket

Tabel 9. Optimasi Jitter Setelah Penerapan HTB

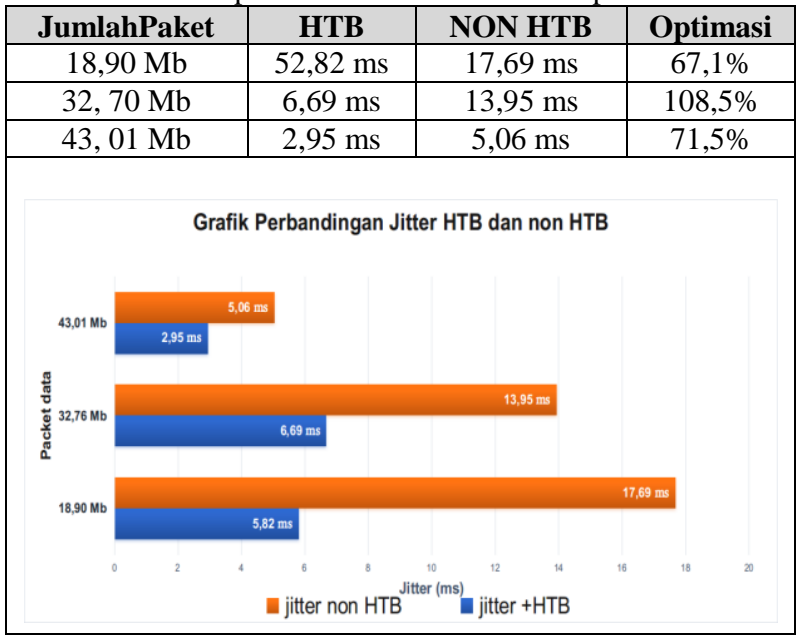

Gambar 10.Perbandingan jitter HTB dan non HTB

\section{KESIMPULAN}

berdasarkan hasil rangkaian uji coba dan analisis penelitian yang sudah dilakukan, maka dapat disimpulkan bahwa (1) Penerapan manajemen bandwidth dengan metode HTB telah berhasil memaksimalkan bandwidth, sehingga kualitas pelayanan bandwidth menjadi meningkat. (2) dengan mengimplementasikan Manajemen bandwidth menggunakan metode HTB maka pengaturan bandwidth untuk user dapat terbagi secara merata.

\section{DAFTAR PUSTAKA}

[1] Saleh, A., Fellow., Simmons, IEEE. "Technology and Architecture to Enable the Explosive Growth of Internet," in IEEE Communications Megazine, vol.49, no.1, pp.126-132, january 2011, IEEE 2011

[2] Wulandari, R. "Analisis QoS (Qualilty of Service) pada Jaringan Internet (Studi Kasus : UPT Loka Uji Teknik Penambangan Jampang Kulon-Lipi," Jurnal Teknik Informatika dan Sistem Informasi, vol 2, no.2, Agustus 2016

[3] Kozacinski, H., Knezevic, P."Configuration of Quality of Service Parameter in Communication Networks," in Procedia Engineering 69 (2014) 655-664, Elsevier 2014.

[4] Odinma, AC., Oborkhale L."Quality of Service Mechanisms and Challenges for IP Networks," The Paciafic Journal of Science and Technology, vol.7 no 1. May 2006.

[5] Firouiu, V., Boudec, Y., Towsley D., Zhang Z."Theories and Models for internet Quality of Service," Proceddings of the IEEE, May 2002.

[6] Sucipto, A., Bandung, Y."Stereotypes Based Resource Allocation for Multimedia Internet Service in Limited Capacity Network," in International Symposium on Electronics and Smart Device (ISESD), 29-30 November 2016.

[7] Bhattacharjee, T., Gopal, V., Nganggoua, LN., Raghunanth, C."TrafficLight: Network Traffic Monitoring and Allocation,"<http://people.cs.vt.edu/ tirtha23/CSGrad/TrafficLi ght.pdf> [diakses 28 mei 2018]

[8] Kassim, M., Ismail, M., Jumari, K., Yusof, M.I."A Survery: Bandwidth Management in an IP Based Network," <https://waset.org/publications/3739/a-survey-bandwidthmanagement-in-an-ip-based-network> [diakses 28 mei 2018]

[9] Richmond, K., Shade, K., Samson, O., Aderonke, A."Management and Control of Bandwidth in Computer Network," in IRACST - International Journal of Computer Network and Wireless Communication (IJCNGambar 9.Perbandingan Packet Loss HTB dan non HTBWC), Vol.2, No.3, June 2012.

[10] Siahaan, MDL., Panjaitan, MS., Siahaan, APU."MikroTik Bandwidth Management to Gain the user prosperity Prevalent, " in International Journal of Engineering Trends and Technology (IJETT)-Vol.42, No.5, December 2016.

[11] Mikrotik Documentation. 2011. "Manual HTB" https://wiki.mikrotik.com/wiki/Manual:HTB> [diakses $2008 \mathrm{Mei}$ 2018]

[12] Cyberoam, White Papper."An Introduction to Load balancing and Failover: what to look for when going for multiple gateways," <https://www.cyberoam.com/downl-loads/Whitepaper/WhitePaper-on-Load-balancing-and-failover.pdf $>\quad$ [diakses 30 mei 2018]

[13] Obadia, M., Bouet, M., Leguay, J., Phemius, K., Iannone, L."Failover Mechanismes for Distribured SDN Controllers," In International Conference and Workshop on the Network of the Future (NOF) 3-5 Dec 2014, IEEE Explore Juni 2015.

[14] ECESSA, White Papper"Everything you need to know about network failover," <http://www.ecessa.com/wpcontent/uploads/2015/02/Everything-You-Need-To-Know-AboutNetwork-Failover.pdf> [diakses 30 mei 2018]

[15] Sudarsono, A., Siswanto, A., Iswanto, H., Setiawan, Q."Traffic Analysis of Quality of Service (QoS) for Video Conferencing between Main Campus and Sub Campus in Laboratory Scale," in EMITTER - International of Engineering Technology, Vol.3, No.2, December 2015. 